\title{
The Relation Between Parent's Role and Children's Brushing Techniques Toward Gingivitis Incident on Children from Selected Primary School in Cimahi
}

\section{Dwi Ardyna Octa Sari ${ }^{1}$, Asep Dian Abdillah², and Dyan Kunthi Nugrahaeni ${ }^{2}$}

${ }^{1}$ Postgraduate Student Faculty of Public Health, Universitas Indonesia, Depok, Indonesia

${ }^{2}$ Program Study of Public Health, School of Health Science Jenderal Achmad Yani Cimahi, Indonesia

\section{Abstract}

Gingivitis is inflammation of the gingiva tissue. The impact of the occurrence of gingivitis is a change in the form of the gingiva, bleeding and painful when brushing teeth as well as halitosis (bad breath). In Indonesia, gingivitis is still in the second place as most common problem faced by society. This research aimed to find out the relation

Corresponding Author: Dwi Ardyna Octa Sari dardynaoctas@gmail.com

Received: 26 December 2018 Accepted: 23 February 2019 Published: 7 March 2019

Publishing services provided by Knowledge E

(c) Dwi Ardyna Octa Sari et al. This article is distributed under the terms of the Creative Commons Attribution License, which permits unrestricted use and redistribution provided that the original author and source are credited.

Selection and Peer-review under the responsibility of the $2 \mathrm{nd}$ International Meeting of Public Health 2016 Conference Committee. between parent's role and children's brushing techniques toward gingivitis incident in SDN Cipageran Mandiri 2. The research design used analytic survey with case-control design with comparison 1:1. the amount of the samples was 60 cases and 60 control. Result from this research showed that the parent's role less was $51.7 \%$ on children with gingivitis, and $66.7 \%$ was from brushing the teeth of gingivitis children with the wrong technique. There was no relation between parent's role to gingivitis incident in children, and there was relation between children's tooth brushing technique to gingivitis incident in children from selected primary class with $\mathrm{p}$-value $=0.027$ and $\mathrm{OR}=$ 2.444. Puskesmas Cipageran and SDN Cipageran Mandiri 2 should organize UKGS activities including health promotions periodically and early screening toward gingivitis, and working together with parents through school committee to give the knowledge about how to maintenance dental health on their children.

Keywords: Gingivitis incident, parent's role, toothbrushing techniques

\section{Introduction}

Dental and oral health problems such as dental caries, gingivitis, and stomatitis at schoolage group become an essential concern in health development. One of them is caused 
The frequency of cleaning the teeth and mouth as a form of behavior will influence whether good or bad oral hygiene, which will affect the rate of caries and periodontal disease (Anitasari \& Rahayu 2005). The most frequent diseases of the periodontal tissues are gingivitis and periodontitis (Situmorang 2004).

Gingivitis is an inflammation of the gum tissue (gingiva) is common and can occur any time after teething (Kusumawardani 2011). Impact of gingivitis is the change in shape of the gums (gingiva), bleeding and pain when brushing your teeth, as well as halitosis or bad breath. Gingivitis affects more than $80 \%$ of children younger age, while nearly all of the adult population have experienced gingivitis, periodontitis or both (Wiyatini et al. 2009).

The Indonesian Dentists Association (IDA), worldwide gingivitis prevalence is $75-90 \%$. The prevalence of gingivitis in Indonesia reaches 96.58\% (Karim et al. 2013) and still becomes the second place in a problem of society. (Wahyukundari 2009). The proportion of people with dental and oral problems including gingivitis disease in West Java according to the characteristic of age from $5-9$ years is $28.9 \%$ (Riskesdas 2013). Cases of oral and dental diseases, including gingivitis and periapical tissue in children selected class (primary 1,3 and 5) in Bandung amounted to 315,441 children (Dinkes Bandung 2014), whereas in Cimahi in Puskesmas Cipageran there were 2,565 people with the same case (Dinkes Cimahi 2014).

Gingivitis that occurs in children is not a serious condition as adults, due to the differences in the quantity and quality of bacterial plaque (Karim et al. 2013). Total accumulation of plaque in children varies according to the frequency of brushing their teeth (Gopinath et al. 2015).

Brushing teeth for school-age children is an act of dental health care which can reduce dental and oral diseases such as gingivitis (Sutjipto et al. 2013). The relationship between brushing teeth and gingivitis are easily demonstrated. Every dentist considers that the plaque deposits associated with gingivitis and prevention of gingivitis are brushing teeth efficiently.

The role of parents is significant in the dental health of children. Parents are required to guide, to give understanding, remind, and provide facilities to the children, to form a child's behavior that can maintain the cleanliness of your teeth and mouth.

Based on what has been described above, the researcher is interested to know parents' role and technique of brushing child's teeth toward incidence of gingivitis in children for a selected primary class at one of primary school mentored by Puskesmas Cipageran Cimahi. Decision-class selected was based on the Guidelines for dental school issued by the Ministry of Health 1996, namely class 1, 3 and five primary school. The UKGS activities were conducted by Puskesmas Cipageran new done for SDN 
Cipageran Mandiri 2 on March 2015 with the total target 456 students and got about 448 students by the number of students who were diagnosed with caries was about 315 students and the number of students who were diagnosed with gingivitis were 162 students. This research aimed to find out the relationship between parent's role and children's brushing techniques toward gingivitis incident in SDN Cipageran Mandiri 2.

\section{Methods}

The study design used in this study was a case-control. The sample in this study was primary 1.3 and five at SDN Cipageran Mandiri 2. The cases were 60 children with a diagnosis of gingivitis, while the controls were 60 children who did not suffer from gingivitis. Gingivitis status obtained from medical records' Puskesmas Cipageran.

The factor that examined was the role of parents and the techniques of brushing teeth. The purpose of parents was assessed by a questionnaire that asked about watching the children to brush their teeth, keeping an eye snacks child, controlling the time of brushing teeth, providing toothbrush and toothpaste, and checking the condition of the child's teeth to health services. A useful role was defined by scoring more than the value of 11 , and a lousy part was less than the amount of 11 while brushing teeth technique was obtained by direct observation from the researcher. The observation of brushing teeth technique used the Bass technique based on the recommendation from a dentist and dental nurses at Puskesmas Cipageran.

Data analysis used univariate analysis to see the picture of distribution and frequency, and bivariate analysis was conducted to see the relationship between independent variable and dependent variables using chi-square and Odd Ratio (OR) analysis to determine the level of risk in the case group and the control group. The significant test in this study used significance limits value $\alpha$ (alpha) $=0.05$ and 95\% Confidence Interval. Data analysis used SPSS for Windows.

\section{Results}

The results of the distribution and the frequency from occurrence variable gingivitis and the role of parents and the techniques in brushing teeth child showed that the purpose of parents was less about $51.7 \%$ for children with gingivitis. The methods of brushing teeth that were not correct were about $66.7 \%$ for children with gingivitis (Table 1 ).

The results of the statistical analysis tests on the parents' role in dental health care of children toward the incidence of gingivitis obtained $p$-value $=0.272$, concluded that 
there was no relationship between parents' role in the incidence of children with gingivitis. The results obtained by analysis of the OR value was 1.603 , so the purpose of parents variable was not the risk factors that caused gingivitis (Table 1).

The results of the statistical analysis tests in children's brushing teeth technique on the incidence of gingivitis obtained $p$-value $=0.027$, concluded there was a relationship between techniques brushing teeth of the children on the impact of gingivitis. The results obtained by analysis of the amount of OR was 2.444 , showing a child with not straight brushing teeth technique had 2.4 times to have gingivitis than those with the correct brushing teeth technique (Table 2 ).

To measure the risk of gingivitis in children whose brushing teeth techniques was not correct, it used the formula of Attributable Risk (AR):

$$
A R=\frac{(O R-1)}{O R} \times 100 \%
$$

Description:

$$
\begin{aligned}
& \mathrm{OR}=\text { odds ratio }(2.444) \\
& \mathrm{AR}=\frac{(2.444-1)}{2.444} \times 100 \%=59 \%
\end{aligned}
$$

Based on the formula above, it was obtained the value of $A R=59 \%$ which meant that the amount of risk to occur gingivitis in children whose not correct brushing teeth techniques was $59 \%$.

TABLE 1: Distribution The Relationship of Parents' Role in Oral and Dental Health Care of Gingivitis Incident in SDN Cipageran Mandiri 2.

Parent's Role
Less
Good
Total

\begin{tabular}{|c|c|c|c|}
\hline \multicolumn{2}{|c|}{ Gingivitis } & \multicolumn{3}{|c|}{ No Gingivitis } \\
\hline $\mathbf{N}$ & $\%$ & $\mathbf{N}$ & $\%$ \\
\hline 31 & 51.7 & 24 & 40 \\
\hline 29 & 48.3 & 36 & 32.5 \\
\hline 60 & 100 & 60 & 100 \\
\hline
\end{tabular}

\begin{tabular}{|c|c|}
\hline \multicolumn{2}{|c|}{ Total } \\
\hline $\mathbf{N}$ & $\%$ \\
\hline 55 & 45.8 \\
\hline 65 & 54.2 \\
\hline 120 & 100 \\
\hline
\end{tabular}

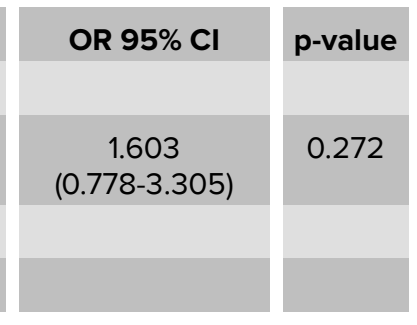

TABLE 2: Distribution of Brushing Teeth Technique in Children toward Gingivitis Incident in SDN Cipageran Mandiri 2.

$\begin{aligned} & \text { Brushing } \\ & \text { technique }\end{aligned}$
No True
True
Total

\begin{tabular}{|c|c|c|c|}
\hline \multicolumn{2}{|c|}{ Gingivitis } & \multicolumn{3}{c|}{ No Gingivitis } \\
\hline N & $\%$ & N & $\%$ \\
\hline 40 & 66.7 & 27 & 45 \\
\hline 20 & 33.3 & 33 & 55 \\
\hline 60 & 100 & 60 & 100 \\
\hline
\end{tabular}

\begin{tabular}{|c|c|}
\hline \multicolumn{2}{|c|}{ Total } \\
\hline $\mathbf{N}$ & $\%$ \\
\hline 67 & 55.8 \\
\hline 53 & 44.2 \\
\hline 120 & 100 \\
\hline
\end{tabular}

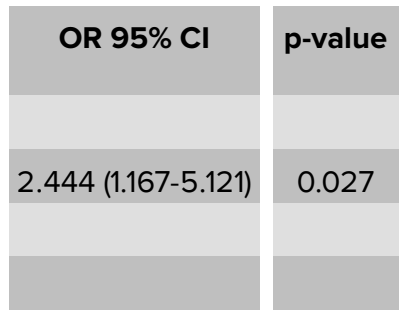




\section{Discussion}

Based on the results, it showed that the univariate analysis of the role of parents in children was $51.7 \%$ with gingivitis and about $40 \%$ in children who did not suffer from gingivitis.

One of the critical roles of parents in improving oral health was to supervise the children and to control the children's time to brushing teeth. The formation of the pattern of behavior in children was influenced by a factor in family, parents, friends, and health workers (Rahmawati et al. 2011). Mother had an essential effect on children's behavior. Good habits instilled by mothers to their children in an environment family would be behaviors settled in children.

Based on the research, it's obtained the univariate analysis on the incorrect brushing teeth technique for gingivitis children were about $66.7 \%$ and about $45 \%$.

Brushing teeth was a major supporting factor for oral hygiene and was a method often used to control bacteria in a plaque at the supra and subgingival and reduce the risk of caries, gingivitis, periodontitis and tooth loss early age (Anggraini \& Arimbi 2014).

At the time of observation brushing teeth in the field, the researcher found some children brushing their teeth by storing the toothbrush vertically, and some children also experiencing bleeding when brushing teeth - bleeding when brushing the child's teeth was caused by brushing teeth too fast and strong or it could cause an inflammation of the gums or gingivitis.

The results based on table 2 showed statistical test $p$-value $=0.272$, concluded that there was no relationship between parents' role of gingivitis incident for primary school children in the selected selected class in SDN Cipageran Mandiri 2. From the results of the analysis, obtained the value OR $=1.603$ (95\% Cl: 0.778-3.305), indicating that the role of parents was not a risk factor for the incidence of gingivitis.

This was in line with research conducted by Astoeti et al. (2003, in Rahmawati et al. 2011) which showed oral health in primary school children was not caused by supportive of their parents, but the child's behavior in brushing teeth, eating sweets and children's toothpaste.

This could happen because of the role of parents (attitudes, behavior, and knowledge) did not guarantee directly toward behavior children everyday to take care their oral hygiene. Besides, the parents had an essential role in shaping children behavior and became a indirect variable to the dental health of their children..

The absence of a significant relationship between parents' role and gingivitis was the result obtained by statistics, Rahmawati et al. (2011) said that the family environment, 
especially parents had a major role in developing positive attitudes towards oral health. The involvement of parents in developing a pattern of positive behavior in the maintenance of health oral and dental should be implemented in children in everyday life either directly or indirectly by way of a facilitator by providing a toothbrush and toothpaste, supervising children brushing teeth, teaching and controlling the timing of brushing, supervising children's snack, then taking and examining the child to the dentist regularly every 6 months for caring.

The results based on table 2 concluded that there was a relationship between the teeth brushing technique in the children and the incidence of gingivitis in children in SDN Cipageran Mandiri 2. From the analysis results, it was concluded that the teeth brushing technique was a factor for gingivitis. The children with the wrong techniques in brushing teeth had $59 \%$ of risk of gingivitis compared to the children with the correct technique in brushing teeth. The wrong technique in brushing teeth affects gingivitis because plaque will remain along with the gum line, causing an irritation and an inflammation (Kusumawardani 2011).

Most children did not brush their teeth correctly because did not notice or did not follow the instruction performed by the UKGS activists, causing them easily to get infection on their gum or gingivitis (Wiyatini et al. 2009).

This was consistent with research Sutjipto (2013), saying that brushing teeth in children aged school may reduce gum disease such as gingivitis. Dental hygiene could be done by brushing your teeth at least two times a day after meals and before taking a bed to inhibit to the growth of bacteria in the mouth that can cause gingivitis.(Wiyatini, et al,2009) (Andlaw \& Rock 1992).

\section{Conclusions}

This study concluded that there was no relationship between the parent's role and the incidence of gingivitis in the children; the technique of teeth brushing and the prevalence of gingivitis in the children. Children with the wrong technique in brushing teeth had 2.4 times or $59 \%$ of risk to have gingivitis compared to the children with the correct technique in brushing teeth. Puskesmas Cipageran and SDN Cipageran Mandiri 2 must conduct activities UKGS including regular health promotion and early screening in the incidence of gingivitis, and join together with parents through committees to provide knowledge regarding the oral health care in children. 


\section{Acknowledgments}

The author would like to express sincere gratitude to dr. Lhuri Dwianti Rhamartani.M.Epid for reviewing my full paper.

\section{References}

[1] Andlaw\&Rock. 1992. Perawatan Gigi Anak. Translater Djaya A,drg. Jakarta: Widya Medika.

[2] Anggraini dan Arimbi. 2014. Perbedaan Skor Plak terhadap Penggunaan Sikat Gigi Konvesional dengan Sikat Gigi Berlampu sebagai Pengukur Waktu.Jurnal Kesehatan UMY. Thesis.umy.ac.id/datapublik/t39155.pdf (Accessed March 12, 2015).

[3] Anita\&Rahayu. 2005. Hubungan Frekuensi Menyikat Gigi dengan Tingkat Kebersihan Gigi dan Mulut Siswa Sekolah Dasar Negeri di Kecamatan Palaran Kotamadya Samarinda. Majalah Kedokteran Gigi. Journal.unair.ac.id/filepdf/DENTJ-38-2-10.pdf (Accessed March 12, 2015).

[4] Dinas Kesehatan Kota Cimahi, 2014.

[5] Gede et.al.2013. Hubungan Pengetahuan Kebersihan Gigi dan Mulut dengan Status Kebersihan Gigi dan Mulut pada Siswa SMA Negeri 9 Manado. Jurnal e-Gigi (eG), Volume 1, Number 2, September 2013: 84-88.

[6] Gopinath, dkk. 2015. Assessment of Gingival Health among School Children in Sharjah, United Arab Emirates. European Journal of Dentistry. www.ncbi.nlm.nih.gov/ pubmed/25713482 (Accessed March 10, 2015).

[7] Karim, dkk. 2013. Gambaran Status Gingiva pada Anak Usia Sekolah Dasar di SD GMIM Tonsea Lama. Ejournal unsrat. Ejournal.unsrat.ac.id/index.php/egigi/article/.../3227 (Accessed March 19, 2015).

[8] Kusumawardani. 2011. Buruknya Kesehatan Gigi dan Mulut. Yogyakarta: Hangar Kretor.

[9] Pedoman Pelaksanaan Usaha Kesehatan Gigi Sekolah 1996.

[10] Profil Kesehatan Dinas Kesehatan Kota Bandung, 2014.

[11] Profil Kesehatan Indonesia 2013.

[12] Rahmawati, dkk. 2011. Perilaku Kesehatan Gigi dan Mulut pada Anak Usia Sekolah Dasar. Berita Kedokteran Masyarakat. Journal.ugm.ac.id/bkm/article/view/ (Accessed March 12, 2015).

[13] Situmorang,N. 2004. Profil Penyakit Periodontal Penduduk di 2 Kecamatan Kota Medan Tahun 2004 Dibandingkan dengan Kesehatan Mulut Tahun 2010 (WHO). 
Dentika Dental Jurnal. https://ml.scribd.com/doc/47867499/Nurmala-1 (Accessed March 14, 2015).

[14] Sutjipto, dkk. 2013. Gambaran Tindakan Pemeliharaan Kesehatan Gigi dan Mulut Anak Usia 10-12 tahun di SD Kristen Eben Haezar 02 Manado. Ejournal Unsrat. Ejournal.unsrat.ac.id/index.php/ebiomedik/.../4150 (Accessed March 12, 2015).

[15] Wahyukundari. 2009. Perbedaan Kadar Matrixmetalloproteinase-8 setelah Scaling dan Pemberian Tetrasiklin pada Penderita Periodontitis Kronis. Jurnal Naskah PDGI. Pdgi.or.id/...jurnal-1-naskah_PDGI_2008_-_Naskah_... (Accessed March 14, 2015).

[16] Wiyatini, et al. 2009. Faktor-faktor Lokal dalam Mulut dan Perilaku Pencegahan yang Berhubungan dengan Periodontitis (Studi Kasus di 3 Puskesmas Kabupaten Demak). Artikel Publikasi. http://eprints.undip.ac.id/5284/ (Accessed March 12, 2015). 